\title{
LEGISLAÇÃo
}

\section{LEIS FEDERAIS E LEIS ESTADUAIS}

\author{
Vitor Nunes LEAL
}

\begin{abstract}
SUmÁrio : - Característica ossencial das federaçöes. Traça principais do federalismo brasileiro. A questão da prevalência da leis federais. $A$ atual situação transitória dos Estados.
\end{abstract}

\section{CARACTERISTICA ESSENCIAL DAS FEDERAÇOES}

1. A caracterização do estado federal é um problema tormentoso, pela dificuldade extrema de distingui-lo do estado unitário descentralizado. Em ambos notamos a coexistência, num mesmo território e sôbre os mesmos cidadãos, de duas esferas de govêrno : a geral e a local. Por isso mesmo há de ser completada com esclarecimentos mais detalhados a fórmula de BRYCE, quando diz: "O que caracteriza o estado federal é justamente o fato de, sôbre um mesmo território e sôbre as mesmas pessoas, se exercer, harmônica e simultâneamente, a ação política de dois governos distintos, 0 federal e o estadual"..'

Já se tem dito que o regime federativo não é um esquema rígido. Ha gradaçōes no federalismo, o que nos levaria a dizer que há estados mais federais, ou menos federais, conforme a predominância, ou não, de certos traços. Teríamos, pois, federações mais perífeitas ou menos perfeitas, segundo o tipo ideal que se prefere. Geralmente, são os Estados Unidos tomados como exemplo histórico da federação completa. Quanto mais um estado, dito federal, se distancia das linhas características do sistema americano, mais discutivel se torna a sua natureza federativa. Quanto mais se aproxima do estado unitário, afastando-se do modêlo histórico, menos perfeita é a federação.

1 Citado por Quzró́s Lnca, Tearia do Estado, 4.: ed., Rio, 1943, p. 240. Näo cabe neste artigo um exame das diversas teorias sôbre o estado federal. As obras de Lr. Fur, Etat Fédétal et Confédération d'Etats, - de Mousturen, La Théorio Juridique le l'Etat Fédéral dfio-nos um panorama ilustrativo do choque de opinióes nesse terreno. 0 livro de Durand, Les Etats Fódéraux (étude de droit constitutionnel positif), Paris, 1930, $6 \mathrm{um}$ excelente estudo comparativo do diverson Estadon babitualmente chamados federais. 
Partindo, pois, do modêlo, isto é, do tipo considerado maiss característico, notamos, desde logo, uma diferença fundamental entre - govêrno estadual da fećeração $\epsilon$ o govêrno local do estado uni.. tário descentralizado. No estado unitário descentralizado, a compe. tência autônoma do govêrno local está na dependência do poder legislativo central. As leis ordinárias do govêrno central podem restringir a autonomia dos governos locais . Na federação, porém, a autonomia dos governos estadusis está fora do alcance do poder: legislativo federal, está submetida apenas ao poder constituinte dá União. As leis ordinárias da União não podem limitar a autonomia dos Estades-membros. Essa autonornia é regulada na Constituịção e só se restringe por ato do poder constituinte federal, isto é, por emende constitucional.

Estas explicações são dadas, com muita clareza, por C. F. STRong, que estabelece, para as federações mais completamente desenvolvidas, os seguintes caracteres : $1^{\circ}$ ) rigidez da constituição, isto é, exigência de formalidades mais severas para as reformas constitucionais do cue para a elaboraçäo das leis ordinárias; $2 .^{\circ}$ ) repartição das competências federal a estadual, feita no texto constitucional; finalmente, $3^{\circ}$ ) existência de uma autoridade suprema para solver as disputas entre a União e os Estados, zelando pela coexistência das duas ordens de competência (federal e estadual) e impedindo as recíprocas usurpações. Tal é o regime dos Estados Unidos, onde a Côrte Suprema é o vigia mázimo das prescrições da Constituição, em cujo texto figura a discriminação das competências federal e estadual.

São suas palavras: "Thus, completely developed federalism shows three clearly marked characteristics -- first, the supremacy of the constitution, that is to say, the ultimate power is the document itself upon which the federalisma is established; secondly, the distribution of powets between the federal state and the co-ordinate states forming $i t ;$ and thirdly, some supreme authority to settle any dispute which may arise between the federal and state authorities. Not all states which we call fedioral states are exactly like this. Federalism is, in fact, of varying shades of completeness and exactitude". =

Segundo êsse ensinamento, a essência da descentralização administrativa e política da federação reside em estar a extensão dessa descentralização fora do alcance do poder legislativo central, o quı não sucede no estado unitário descentralizado. O contrôle de cons-

2 C. F. STRONG, Modorn Folitical Constitutions - - An introduction to the compa. ratipo otudy of their history and existing form - Revised and onlarged edition, Loodon, 1939, p. 61 . 
titucionalidade por um órgão diferente do poder legislativo central constitui um aperfeiçoamento do sistema. Sem êle, o poder legislativo central poderia fraudar a definição constitucional das competências federal e estadual, promulgando leis inconstitucionais, com invasão da esfera de competência dos Estados. Sendo o legislativo federal o único juiz da constitucionalidade de suas leis, a invasão da competência privativa dos Estados ficaria consumada sem apêlo, com evidente desfiguração da rigidez ou supremacia do texto constitucional.

Mas o papel que êsse órgão (a Suprema Côrte nos Estados Unidos) desempenha pode ser suprido por outros processos politicos eficazes, que de fato garantam o respeito às linhas divisórias das competências federal e estadual. Assim ocorre na Suíça. onde os poderes do parlamento, que é o único juiz da constitucionalidade das leis, estão cerceados pela ação vigilante de uma opinião pública esclarecida e organizada, através dos institutos do referendum e da iniciativa popular. $O$ que é preciso, pois, é que a supremacia da Constituição sôbre as leis encontre amparo em processos eficazes, evitando-se por êsse modo que a União usurpe atribuições dos Estados, ou que os Estados invadam o campo de competência da União. "A base do sistema federativo - diz QunNrana - é a harmonia entre as duas ordens de competência (a federal e a estadual) e que haja meios eficazes para garantir essa harmonia". $\mathbb{E}$ em outro trecho: "Descansando, pois, o edificio federativo no equilíbrio dos poderes centrais e locais, compreende-se fàcilmente que para aquela estruturação política não degenerar e desnaturar-se, é indispensável que, na prática das instituiçōes, se garanta a coexistência harmônica e coordenada das duas ordens de govêrno: a federal e a provincial":

O essencial - insistimos - é que o legislativo federal não possa mutilar a competência estadual configurada no texto da constituição. O traço apontado por LE FUR como característico das feđeraçōes, isto é, a existência de um Senado (ou que outro nome tenha) em que os diversos Estados-membros estejam representados como unidades políticas ", vale como um contrôle prévio, uma garantia a priori da autonomia estadual. Como é essencial o acôrdo dêsse órgão para a elaboração ds leis federais, é de se presumir que os representantes dos Estados-membros não se compactuem com as mutilações que a outra casa do parlamento queira fazer na competência estadual privativa. Nos Estados Unidos, e nos

3 Segundo V. LnNhares QunNTANA, Federalisono y Centraliseción Polftica - Introdacción, "La Ley" de 12-6-942.

4 Ir Fun, Prócie do Droit International Pablic, Parie, 1931, n.• 198, p. 89. 
paises que mais de perto lhes imitaram as instituições, além dêsse contróle prévio que a câmara alta presumivelmente exercerá, ainda existe o contróle a posteriori, ezercido pelo poder judiciário, com o exame da constitucionalidade das leis.

\section{TRAÇOS PRINCTPAIS DO FEDERALISMO BRASILEIRO}

2. A federação brasileira, instituída em 1891, e que se inspirou na norte-americana, assimilou os princípios fundamentais desta ". Nossa Constituição era rígida; os poderes da União e os dos Estados estavam discriminados no texto constitucional; ao Poder Judiciário fó confiado o papel de intérprete final da Constituiçãa podendo deixar de aplicar as leis inconstitucionais. Além disso, uma das Câmaras do Congresso - o Senado - era composto de representantes dos Estados, como unidades políticas.

Estes princípios mantiveram-se na Constituição de 1934 e: com algumas modificações que adiante examinaremos, na Constituição de 1937.

3. Na Constituição de 1891 , ̀̀ semelhança do que ocorre nos Estados Unidos, a divisão de competência oberieceu ao sistema de enumeração dos poderes da União e da entrega dos poderes remanescentes aos Estados. Dispunha o art. 65 :

'E' facultado aos Estados... 2. ${ }^{\circ}$ - Em geral tocic e qualquer poder ou cireito que thes não fôr negado por clánsula expressa ou implìcitamente contida nas cláusulas expressas da Constituição".

Na repartição das competências não foram, entretanto, os Es tados tão aquinhoados como nos Estados Unidos. Cite-se por exern plo, o poder de legislar sôbre direito substantivo (direito civil, c.3 mercial e criminal), que conferimos privativamente à União (ar tigo 34, no 23) e que na república norte-americana ficou, en larga escala, pertencendo aos Estados. Além disso, princípios cons titucionais que entre nós obrigavam igualmente a União e os Es tados (art. 63), como o da absoluta laicidade do Estado (art. 11 n..$^{\circ}$, e art. 72, diversos incisos), são, nos Estados Uniços, obriga.

5 Na sessão solene de promulgaçāo da Constituição do 1891, o presideare da Acara. blèia Constituinte, Prudente de Morais, disse: em seu discurso: "... O Brasil, a nosse pátría de hoje en diante, tem uma constituiçäo lirre e democrática con o regime ả mas axayls federaçäo, único capaz de mantê-lo unido, de fazer cona que possa desenvolver-\$e, pros perar corresponder no América do Sul o eu modêlo da Abúrica do Norte..." (h. TAVARES DE LIRA, Organizagäo Paĺrica Administrativa do Bravil, Rio, 1941, p. 24.6). 
tórios apenas para a União, ficando os Estados com liberdade de dispor em contrário ${ }^{6}$.

Mas o fato de ser mais ampla ou menos ampla a soma dos poderes privativos dos Estados não é o ponto vital do sistema federativo. As federações podem ser mais descentralizadas ou menos descentralizadas. O importante é que a esfera de competência privativa dos Estados (menos ou mais ampla) seja inviolável pelo poder legislativo da Uniāo". Quanto à maior ou menor extensão dos poderes exclusivos dos Estados particulares hão de decidir as circunstâncias históricas e sociais de cada país que adcte a forma federativa. Não se poderia pretender que no Brasil, onde partimos do unitarismo para o federalismo, ficassem os Estados com tão amplos poderes como na federação norte-americana, que proveio de uma confederaçāo, representando, em si mesma, uma etapa centralizadora. E', aliás, tendência-generalizada e constante das federações 0 acréscimo dos poderes da União, num sensível movimento de centralização, em detrimento da competência privativa dos Estados-membros. O fenômeno tem atingido particularmente os Estados Unidos, que é uma federação tradicional e poderosamente descentralizada, e o fundamento principal dessa extensão da competência federal têm sido os poderes implícitos do Congresso.

A nossa Constituição de 1891, reservando para os Estados os poderes remanescentes, não deixou, entretanto, de conferir à União, além dos poderes expressos, também os poderes implícitos (art. 65, 2. , cit.). Idêntica foi a orientação das Constituições posteriores, de 1934 e 1937. Ambas discriminam, com a primeira, os poderes da União e os dos Estados, e ambas igualmente atribuem os poderes remanescentes aos Estados, conferindo à União os pode-

6 Nas palavras de Cióvis BzviLAquA, segundo dispóe a primeira emenda à constitrichio norte-americana, ratificads em 1791 ("Congress shall make no law respecting an establishment of religion or prohibiting a free exercies thereof"), "o Congresso nāo pode votar lei alguma no intuito de estabelecer uma religião qualquer ou de proibir-lhe o livre exercicio. Mas êsse preceito, que se dirige ao Podex Legislativo da União, deira ao critério - ao sentimento dos Estadios particulares regular as relaçöes entre o poder civil e o religioso. Assion que dentro da liberdade de crenças, que as Constituiçōes estaduais assecuram, há restricōes e prẹferências, que tiram, no sistema adotado, o caráter de pura laicidade, que se poderia acteditar resultante da citada emenda" (Estudos Jurídicos, Rio, 1916, p. 253, "O espírito da Constituiçäo Brasileira").

7 "La notion de l'autonomio de l"Etat-membre" ne peut permettre de caractériaer cotte collectivité ai on l'envisace au point de vue des attributions exerces. Cette notion ost a bien une question do degré que los auteurs qui l'adoptent (en y ajoutant la notion de "puisamce originaire") reconnaissent que l'Etat fódéral pourrait se transformer en Etat unitairo par la réduction prodreasive des attributions des "Etats-membros". Reste ceulement 10 tait que la constitution fédérale attribue aux or fenes propres des compétences exclusives, caracterioée non par leur contenu mais par leur existence a l'encontre du lógislateur fédéral Imi-même. C'est le seul criterium jurridique de JEtat fédéral que nous ayons encore rencontré". (CH. Durand, Los Etata Fódéraux, Paris, 1930, ps. 182-3). 
res expressamente enurnerados e os que naqueles estejam implicitamente compreendidos. A de 1934 dispunha (art $7 .^{\circ}$ ):

"Compete privativamente aos Estados... IV -exercer, em geral, todo e qualquer poder ou cireito, que Thes não fôr negado explicita ou implicitamente por cláusula expressa desta Constituição".

A disposição que regula a matéria na Constituição de $193^{\prime} 7$ é a seguinte:

"Compete privativamente aos Estados... II exercer todo e qualquer poder que lhes näo fôr negado. expressa ou implìcitamente, por esta Constituição".

Por conseguinte, conserva-se até hoje, no nosso ordenamento constitucional, o princípio da discriminação das competências federal e estadual feita no próprio texto da Constituição. Este, segundo o critério que acima perfilhamos, é um dos traços característicos do sistema federativo, segundo o modêlo norte-americano.

4. Outro traço característico do regime é, como vimos, a rigidez da constituição. A constituição é rígida, quando o seu valcr jurídico é superior ao das leis ordinárias. A elaboração da constituição ou das emendas constitucionais obedece a trâmites mais severos que os da elaboraçäo das leis ordinárias. Distingue-se nitidamente o poder constituinte do poder legislativo. "La distinction des deux pouvoirs - diz ESMEIN - a passé dans la plupart des constitutions écrites des temps modernes, en Amérique par l'inflinence des Etats-Unis, en Europe par l'influence trançaise"s.

5. Fela Constituição de 1891, a elaboração de uma lei dependia da maioria de votos das duas casas do Congresso e da sanção presidencial (art. 37). Se o projeto fôsse vetado pelo Pres:dente, podia o veto ser removido por dois terços de votos das duas Câmaras na sessão legislativa seguinte (arts. 37 , $\S 30^{\circ}$, e 40). As emendas da Câmara revisora, se confirmadas por dois terços d? votos, ficariam prevalecendo, desde que a outra Câmara não revnisse, para rejeitá-las, igual maioria; mas, contando com dois terçcs de votos, a Câmara que teve a iniciativa do projeto podia impo: sua redução primitiva à Casa revisora (art. 39).

8 Eléments de Droit Constitutionnel Français et Comparé, 8.* ed., revista por Hapre: Nhezard, tomo I, Paris, 1927, I faxte, tit. II, cap. V (Le théorie des constitutions écriter), p. 615 . 
As reformas constitucionais faziam-se por processo mais rigoroso. A reforma só se considerava proposta, quando:

$\left.1^{\circ}\right)$ sendo apresentada por uma quarta parte, pelo menos, dos membros de qualquer das Câmaras, fôsse aceita, em três discussōes, por dois terços dos votos de cada uma das Câmaras; ou

2.. ) quando fôsse solicitada por dois terços dos Estados, no decurso de um ano, representado cada Estado pela maioria de votos de sua assembléia (art. $90, \S 10^{\circ}$ ).

Essa proposta era dada por aprovada, se no ano seguinte, em três discussóes, obtivesse dois terços de votos em cada uma das Casas do Congresso (art. 90, $\S 2 .^{\circ}$ ). A emenda, assim aprovada, incorporava-se à Constituição, não dependendo da sanção presidencial (art. 90, § $3^{\circ}$ ).

6. Na Constituição de 1934, afora disposições peculiares sôbre a iniciativa dos projetos (art. 41), as leis também dependiam da maioria dos votos das duas Câmaras e da sanção presidencial (art. 43), mas em diversas matérias não colaborava o Senado (art. 91) e em outras dispensava-se a sanção presidencial (art. 40). Os poderes das duas Câmaras, uma em face da outra, quando ambas colaboravam na feitura da lei, eram idênticos aos da Constituição anterior: a Câmara revisora podia impor suas emendas à outra Casa, confirmando-as por dois terços de votos; por seu lado, a Câmara em que a discussão tivesse tido início, podia impor o texto primitivo, rejeitando, pela mesma maioria de dois terços, as emendas da Casa revisora (art. 44). O veto presidencial podia ser removido na mesma sessão legislativa pelo voto da maioria absoluta dos membros da Câmara dos Deputados, se o Senado não houvesse colaborado no projeto, ou das duas Casas, quando o projeto tivesse transitado por ambas (art. 45, $\S 2 .^{\circ}$ ).

A reforma constitucional podia assumir duas modalidades emenda ou revisão, e a Constituição enumerava os artigos cuja alteração representava uma ou outra modalidade. Tanto a emenda como a revisão exigiam, porém, formalidades mais severas que as da elaboração legislativa, e não se admitia reforma constitucional durante o estado de sítio (art. 178).

7. A Constituição de 1937 operou, a êste respeito, importantes alterações. Além dos poderes legislativos conferidos ao Presidente da República (arts. 13 e 14), a iniciativa do Parlamento na elaboração das leis foi cerceada (art. 64). O processo normal é a aprovação por maioria ordinária em ambas as Câmaras e san- 
ção presidencial, com audiência do Conselho da Economia Nacional nos projetos de natureza econômica (arts. 65 e 66). O veto presidencial pode ser removido por dois terços dos sufrágios prosentes nas duas câmaras, em votação nominal (art. $66, \S 3 .{ }^{\circ}$ ). Mas, se a matéria da lei fôr das compreendidas no art. 13, poće o Presidente revogá-la, por decreto-lei, nos períodos de recesso óc Parlamento ou de dissolução da Câmara dos Deputados, caso tente sido o projeto aprovado com remoção do veto presidencial ${ }^{\bullet}$.

A reforma constitucional pode revestir três modalidades: $\varepsilon$ primeira, quando o Presidente e o Parlamento estão de acôrdo, as duas últimas, quando êsse acôrdo não existe. Dispõe o art. 174 com a redação que the deu a Lei Constitucional n. ${ }^{\circ}$ 9, de 28-2-1945:

"A Constituição pode ser emendada, modificada or reformada por iniciativa do Presidente da República on da Câmara dos Deputados.

§ 1.0 O projeto de iniciativa do Presidente da República será votado em bloco, por maioria ordinári de votos da Câmara dos Deputados e do Conseiho $\mathrm{Fe}$ deral, sem modificaçōes ou com as propostas pelo Presi dente da República, ou que tiverem a sua aquiescência se sugeridas por qualquuer das Câmaras.

$\S 2 .^{\circ}$ O projeto de emenda, modificação ou refor ma da Constituição, quando de iniciativa da Câmara do Deputados, exige, para ser aprovado, o voto da maioria dos membros de uma e outra Câmara.

$\S 3 .^{\circ}$ O projeto de emenda, modificação ou refor ma da Constituição, quando de iniciativa da Câmara do Deputados, uma vez aprovado mediante o voto da majc ria dos metnbros de uma e outra Câmara, será enviad ao Presidente da República. Este, dentro do prazo i trinta dias, poderá devolver à Câmara dos Deputados . projeto, pedindo que o mesmo seja submetido a nov tramitação por ambas as Câmaras. A nova tramitaçä só poderá efetuar-se no curso da legislatura seguinte, saly quanto ao projeto elaborado na primeira legislatura, qual tramitará durante esta e prevalecerá se obtiver voto de dois terços dos membros de uma e outra $\mathrm{C} \hat{a}$ mara.

9 Consuite-se a respeito a nova retlação dada pela Lei Constitucional n.॰ 9, d 28-2-1945, aos aris. 14,64 e 65 . 
$\S 4 .^{\circ}$ No caso de ser rejeitado o projeto de iniciativa do Presidente da República, ou no caso em que - Parlamento aprove definitivamente, apesar da oposição daquele, o projeto de iniciativa da Câmara dos Deputados, o Presidente da República poderá, dentro de trinta dias, resolver que o projeto seja submetido ao plebiscito nacional. O plebiscito realizar-se-á noventa dias depois de publicada a resolução presidencial. O projeto se transformará em lei constitucional se the fôr favorável o plebiscito".

Da leitura do artigo acima transcrito verifica-se o seguinte:

1. $\left.{ }^{\circ}\right)$ Havendo acôrdo entre o Presidente e o Parlamento, a emenda constitucional é feita por processo mais simples que o das leis ordinárias votadas pelo Parlamento, devido à dispensa da audiência do Conselho Nacional, mesmo quando a reforma atinja disposições de natureza econômica;

2..$^{\circ}$ Havendo desacôrdo entre o Presidente e o Parlamento, pode a reforma, na primeira hipótese, ser operada por maioria especial, igual à que se exige para remoção do veto presidencial. A diferença está em que a nova tramitação só se pode operar na legislatura seguinte, com exceção da primeira legislatura a instalar-se, a qual poderá usar da faculdade de aprovar reforma con乏titucional sem aquiescência do Presidente;

3. ) Finalmente, a segunda hipótese que pode ocorrer no caso de desarmonia entre o Presidente e o Parlamento é o recurso ao plebiscito, processo estranho à elaboração das leis ordinárias."

Não se pode, pois, dizer que na Constituição atual a reforma constitucional obedece sempre a tramitação mais rigorosa que a das leis ordinárias. Pode, ao contrário, em uma hipótese, ser a tramitạção da reforma ainda mais simples que o das leis votadas pelo Parlamento.

Subsiste, entretanto, alguma diferença entre os processos de legislar e de reformar a Constituição. A primeira é que, eventualmente, pode a reforma exigir formalidades mais onerosas que as leis ordinárias (quando há desacôrdo entre o Presidente e o Parlamento). A segunaja é que, embora tenha o Presidente, isoladamente, poderes legislativos originários em muitas matérias (artigos

10 Note-se que a Lei Constitucional n. 9 nāo permite mais que co concedam podere bepialativo ao Conselho da Economia Nacional por via de plebiscito (art. $2 .^{\circ}$, que revogou - art. 63 da Constituição). 
13 e 14), não terá jamais, depois de instalado o Parlamento, , poder constituinte (art. 13, letra a).

De qualquer forma, porém, encontra-se atenuado na Cans tituição êste traço característico das constituiçōes rígidas, que é a exigência de processo mais complexo que o da elaboração das lei ordinárias para as reformas constitucionais. Daí, porém, não łı pode concluir que desapareceu entre nós a rigidez constitucional em primeiro lugar porque nem sempre a reforma constituciona se opera pelos mesmos trâmites da elaboração legislativa ordinảria e, em segundo, porque continua em vigor o princípio de que : Constituição prevalece sôbre as leỉs ordinárias, como veremos no: parágrafos seguintes.

8. Outro princípio que importamos dos Estados Unidos e qu vale como refôrço da tigidez constitucional foi $o$ do contrôle d. Constituição pelo Poder Judiciário. ${ }^{11}$

Na Constituição de 1891, a faculdade que tinha o Judiciáric de negar aplicação às leis inconstitucionais - fôssem da União, d’x Estados ou dos Municípios - resultava, em princípio, da suprema cia do texto constitucional, consistente na distinção entre o podes constituinte e o poder legislativo. Mas êste princípio não era sufi. ciente, porque em países em que o poder constituinte se distinģut do legislativo nem sempre pode o judiciário apreciar a constitu. cionalidade das leis. Assim ocorria na vigência da Constituiçếc francesa de 1875 e da nossa Constituição imperial. Assim ocorre ainda na Suíça e em muitas outras naçōes. Por isso, também no baseávamos na prática das instituições norte-americanas, que havíamos adaptado ao Brasil, e ainda nos dispositivos da Constituição que regulavam a competência do Supremo Tribunal Federal. Quanto à inconstitucionalidade das leis federais, invocávamos c art. 59, $\S 1 .^{\circ}$, letra a, que dava recurso extraordinário para o Supremo, quando se questionasse sôbre a validade ou a aplicação de tratados e leis federais, e a decisão do tribunal do Estado fôsse contra ela. Quanto às leis estaduais e municipais, a letra $b$ do mesmo dispositivo facultava idêntico recurso, quando se contestasse a validade de leis ou de atos dos governos dos Estados eta face da Constituição, ou das leis federais, e a decisão do tribunal do Estado considerasse válidos êsses atos, ou essas leis impugnadas."

11 Veja-se aste respeito CAstro Nunes, Tentia - Prática do Pocer Judiciárie, ad. da Rev. For., Rio, 1943, ps. 581 ss.

12 Na reforma constitucional de $\$ 925$, o inciso acima citado ficou redigido do seguinte modo: "quando se questionar sôbre' a vigéncia, ou a validade das leiı fedonián on face da Constituigéo e a decisão do tribunal do Estado thes negar aplicacăo" (art. 6e, (1.*, a). 
9. Na Constituição de 1934, além de disposições equivalentes no tocante à competência do Supremo Tribunal Federal (art. 76, III,$b$ e $c$ ), havia duas outras muito mais expressivas : o art. 179, ao exigir maioria absoluta de votos para que os tribunais pudessem "declarar a inconstitucionalidade de lei ou de ato do poder público", e o art. 91, IV, que permitia ao Senado "suspender a execução, no todo ou em parte, de qualquer lei ou ato, deliberação ou regulamento, quando hajam sido declarados inconstitucionais pelo Poder Judiciário". Mandava ainda o art. 96 que o Procurador Geral da República comunicasse ao Senado, para os fins do art. 91, IV, as decisões da Côrte Suprema que declarassem inconstitucional "qualquer dispositivo de lei ou ato governamental".

10. Na Constituição atual subsistem os mesmos casos de recurso extraordinário para o Supremo (art. 101, III, b e c), e há ainda a disposição do art. 96 :

"Só por maioria absoluta da totalidade dos seus juízes poderão os tribunais declarar a inconstitucionalidade da lei ou de ato do Presidente da República".

Por conseguinte, ainda o último traço das federaçōes "mais completamente desenvolvidas" apontado por STRong (supra, número 1) e que é a existência de um órgäo especial incumbido de velar pelo mútuo respeito das esferas de poder estadual e federal, através da interpretação do texto constitucional, que prevalece sôbre o das leis ordinárias, ainda êste último traço característico importamos dos Estados Unidos e incorporamos ao nosso ordenamento constitucional.

Entretanto, a Constituição de 1937 estabeleceu uma restrição ao poder dos tribunais em matéria da constitucionalidade, quando dispôs, no art. 96, parágrafo único:

"No caso de ser declarada a inconstitucionalidade de uma lei que, a juízo do Presidente da República, seja necessária ao bem estar do povo, à promoção ou defesa de interêsse nacional de alta monta, poderá o Presidente da República submetê-la novamente ao exame do Parlamento; se êste a confirmar por dois terços de votos em cada uma das Câmaras, ficará sem efeito a decisão do Tribunal".

A última palavra em matéria de constitucionalidade pode vir a caber, não ao Judiciário, mas ao Presidente e ao Parlamento, medida que deu forma jurídica, entre nós, aos reclamos manifesta- 
dos por certos setores do pensamento político e jurídico dos Estados Unidos contra a onipotência da Suprema Côrte. ${ }^{15}$

Entretanto, também não se pode concluir dessa restrição oposita ao Poder Judíciário, na. Constituição de 1937, que ela aboliu a rigidez constitucional, ou seja, a supremacia da Constituiçāo. Em primeiro lugar, porque nem todos os textos legislativos podem ser confirmados pela via excepcional do art 96, parágrafo único, pois, quando estiver reunido o Parlamento, os decretos-leis promulgados pelo Presidente da República, no uso dos poderes do art. 14, não estarão incluídos nesta prerrogativa ${ }^{14}$. Em segundo lugar, porque a faculdade contida no art. 96, parágrafo único, não anula a competência do Judiciário de fazer prevalecer a Constituição sôbre as leis ordinárias. A decisão que assim dispuser pode ficar sem efeito por um novo pronunciamento do legislativo, mas pronunciamento de natureza essencialmente política, para o qual se exige maioria qualificada de votos do Parlamento e exclusiva iniciativa do Presidente da República. O principio jurídico da supremacia da Constituição subsiste na própria afirmação constitucional da possibilidade do Judiciário declarar a inconstitucionalidade das leis. Nem é de se supor que o Presidente e o Parlamento passem a confirmar sistemàticamente as leis declaradas inconstitucionais pelo Judiciário.

11. Esclarecido, como ficou, que a atual Constituição mantém, pelo menos no que toca ao seu alcance jurídico, os princípios fundamentais do sistema federativo, tal como é estruturado nos Estados Unidos, a conclusão inevitável é que a esfera dos poderes; privativos dos Estados continua, entre nós, inacessivel à invasão por parte das leis ordinárias da União. Não se perca, porém, de vista que essa incolumidade da competência privativa dos Estados é sòmente jurídica e não política. Do ponto de vista políticc, existe a possibilidade de redução da competência estadual exclusiva, não só pela faculdade de confirmaçăo de lèis inconstitucionais segundo o disposto no art. 96, parágrafo único, da Constituiçâa, como ainda pela grande facilidade das reformas constitucionais,

13 Vejam-se a respeito : Fruncisco CaMpos, $O$ Estado Nacional, 3." ed., Rio, 1941, ps. 103 ss ; Castro Nunes, Tecria e Prática do Poder Judiciário, já cit., ps. 581 ss. ie os sutôres americancs referidos neste último.

14 Pontes DE Mikanda, Comentários à Constituiçăo Federal de 10 de novembro de 1937, vol. I, 1938, פ. 341 : "Os decretos-leis pars quais o Presidente da Repúblical invoque o art. 14, quando excedentes das atribuiçóen conferidas pela letrs do referda, preceito, sāo inconstitucionais, e não só ilegais, de roodo que é de mister, por serem atom do Presidente da República, a maioria do art. 96 , porém nāo pode o próprio Presidente da República usar da faculdade do art. 96, parág. único, pois o art. 96, parág. único, s6 se refere a atos do Paglamento (verbo "vovarnente"). 
quando o Presidente da República e o Parlamento estejam concordes (art. 174, § $2 .^{\circ}$, e $\S 3 .^{\circ}, 1 .^{\mathrm{a}}$ parte).

A garantia política da competência privativa dos Estados contra as intromissões que a União poderá fazer pelos meios acima apontados reside na composição do Conselho Federal, que foi alterada pela Lei Constitucional n. ${ }^{\circ} 9^{15}$. Mas, nos Estados Unidos e nas nossas Constituições anteriores, essa garantia se encontra reforçada por outras: poder final do Judiciário em matéria de constitucionalidade e exigência de cautelas especiais para reforma da Constituição.

Enfraquecida embora a garantia política da incolumidade da competência privativa dos Estados, subsiste a garantia jurídica, traduzida no princípio da supremacia da Constituição.

Os poderes federais exclusivos constituem uma órbita; os estaduais, quando exclusivos, constituem outra. Essas duas órbitas são independentes entre si, e essa independência é inviolável pela lei ordinária federal. Nisso reside o critério fundamental do sistema federativo. O govêrno federal, nas palavras de Barbalho, "coexiste com os governos dos Estados, tendo cada um sua esfera de ação própria e distinta". Diz ainda êste clássico do nosso direito público: "Outra espécie de órgãos criada pela soberania nacional é o Govêrno Estadual com todos os poderes e direitos que, no plano da Constituição Federal, não foi preciso reservar à União, e no uso dos quais os Estados são tão livres e independentes, isto é, soberanos no círculo que lhes pertence, como no seu é dêles independente a União" ${ }^{16}$

\section{A QUESTÃo da PREVALÊNCIA DAS LEIS FEDERAIS}

12. Em face de tais princípios, devemos acolher com reserva - aforismo de BRYCE sôbre a quádrupla classificação hierárquica das leis no regime federativo, exposta nestes têrmos por RuI BARBosA : "Nos países federalizados, como os Estados Unidos, como - Brasil, a escala é quádrupla : a Constituição Federal, as leis

15 No texto primitivo da Constituiçäo, o Conselho Federal os comporia de um representante de cada Estado e de dex membros nomeado pelo Presidente da República (art. 50). A Lei Constitucional n. 9 suprimiu os conselheiros de nomeaçäo presidencial, incluiu o Distrito Federal no Conselho, e aumentou para dois membro a representação de cada unidade.

16 Constitucição Federal Brasileira, por JoXo Barbalho U. C., Rio, 1902, p. 9. Bambalno sustenta a doutrina da soberania dos Estadoo-membros. Näo cabo aqui di. cutirmos êsse ponto de vista. Mas como, na liçâo do mestre, cesa soberania estadual 6 retrita aos poderes privativos dos Estados, as suas palavras continuam verdadeiran, abstraindo do têrmo soberania, que comporti sentido mais amplo e com repercussấo no plano internacional. 
federais, as Constituições dos Estados, as leis dêstes. A sucessãa, em que acabo de enumerá-las, exprime-lhe a hierarquia legal. Dado o antagonismo entre a primeira e qualquer das outras, entre a segunda $e$ as duas subseqüentes, ou entre a terceira e a quarte, à anterioridade na graduação indica a precedência na autoridade." A. Gonçalves DE OLIVEIRA, em erudito e seguro artigo, publicadic recentemente, insistiu nessa advertência, expondo a boa doutrina. ${ }^{3 . s}$

$O$ equívoco em que se pode incidir reside na formulação geate rica da aludida hierarquia, subordinando-se as Constituiçōes e as leis estaduais às leis federais, sem estabelecer nenhuma restrição à expressão "leis federais". A hierarquia existe, mas, em vez da simples expressão "leis federais", deve dizer-se "leis federais válidas", isto é, expedidas dentro da competência da União e que não infrirjam qualquer proibição constitucional. Assim, quando o ministro Castro Nunes, ao estudar os casos de recurso extraordinário, declara que, havendo conflito entre uma lei federal e uma local, esta última "terá de ceder à de maior autoridade, a federal"19, havemos de entender que se refere a lei federal válida. A rstrição da validea da lei federal está implícita na enumeração hierárquica de que falamos.

Essa restrição, que está expressa na Constituição dos Estado: Unidos", não é esquecida pela doutrina americana. Diz MatHEws professor de ciência politica na Universidade de Illinois: "T The powers of the latter (govêrno nacional) are also delimited by the Constitution, and, IN ITS OWN SPHERE, it is not subject to control by the states." $\mathbf{E}$ em outro trecho, mais expressivo porque destinado $\mathrm{a}$ resolver a questão do conflito entre leis estaduais e federais : "Ornt difficulty which arises in operating the federal form of governmeni is that there may be conflicts between the laws passed by the Na tional Government and those passed by the states... In case D: doubt or controversy, the supremacy of national law IN ITS Ows

17 'E' bem conhecida - diz PEDRo LEssa -.. a gradução que o regime federal - abtableceu entro as disposiçöes constitucionais e legais da Uiniăo e dos Estados. Ex primeiro lugar está a Constituị̧̧ăo Federal, que prevalece sôbre tôdas as mais leis federaị - locaib; em segundo lugar as leis federais; em terceiro as corstituicöea do Eatados; eja quarto as leis dos Estados". (Do Poder judiciátio, 1915, p. 116).

18 A. Gonçalves DE Outverra, Hierarquia das Leis e Competência Legislativa c'a Uniāo - dos Estados, em Arquivos do Ministério da Justiça e Nefócios Inreriores, n." B escósto, 1944, pe. 42 ss.; Rev. do Serviço Público, fereveiro, 1945, p. 85).

19 "Ora, miz das hipóteses figuradar an letra $c$ " (do artigo 101, MX, da C.F.) "á a de colisāo entre leis, leis de hierarquia diversa, lei tederal, uma, lei local, outra - una das quais, enta última, terá de ceder i de maior autoridada, a federal". ( $T$ eoria Prática do Poder Judiciário, edição Rev. For., Rio, 1943, p. 375, line).

20 This constitution, and the laws of the United Statea which thall be made in pursuasce thercof... shall be the supreme low of the land"... (art. VI). 
SPHERE is enforced by the courts."21 A lição baseia-se no texto do art. VI da Constituição americana, que o autor transcreve.

A doutrina não pode deixar de ser a mesma entre nós. As leis federais prevalecem sôbre as Constituições e leis estaduais, mas não nos esqueçamos : leis federais válidas. Para que a lei federal seja válida é preciso: $1^{\circ}$ ) que regule matéria da competência da União, isto é, que tenha sido baixada pela União na esfera de sua competência ("in its own sphere" - diz Mathews), e $2 .^{\circ}$ ), que, embora conforme com as regras constitucionais de competencia, não desrespeite qualquer outra disposição constitucional. Quer infrinja a primeira, quer infrinja a segunda recomendação, tanto num como noutro caso, a lei federal não será válida, porque é inconstitucional, e, sendo inconstitucional, não pode ser aplicada, ficando fora de propósito a questão da sua prevalência sôbre leis estaduais. Por isso, diz A. Gonçalves de Oliverra ! "Não existe, em princípio, uma supremacia da lei federal... O problema é, antes, de constitucionalidade ou inconstitucionalidade das leis." ${ }^{22}$ Realmente, no domínio das competências privativas, a declaração da prevalência da lei federal consiste, substancialmente, na declaração da inconstucionalidade das leis estaduais que com ela estejam em conflito. Na competência concorrente, porém, a supremacia da lei federal é indiscutível. E o desrespeito às leis federais por parte dos Estados chega a justificar a intervenção federal nestes". Por isso mesmo, como existe nos regimes federais uma questão de preponderância da lei federal (competência concorrente), ao lado de uma questão de constitucionalidade (competências exclusivas), a conhecida regra da hierarquia das leis na federação é perfeitamente acertada, desde que se entenda que sòmente as leis federais válidas preponderam sôbre as estaduais.

13. Confere, porém, a nossa Constituição (art. 101, III, c) recurso extraordinário para o Supremo Tribunal Federal nas causas em que "se contestar a validade de lei ou ato dos governos locais em face da Constituição, ou de lei federal, e a decisão do tribunal local julgar válida a lei ou o ato impugnado". As constituiçōes anteriores continham o mesmo dispositivo, com pequena diferença de redação". Em face dessa norma não se deve, porém,

21 The American Constitutional System, by Jokn Mank MATkFws, Ph. D., Second edition revised and enlarged, Now York and London, 1940, pu. 22 e 23.

22 Trab. cit., p. 46.

23 Const. de 1937, art. 9.॰; Conat. de 1934, art. 12 ; Const. de 1891, art. 6.^.

24 Const. de 1934, art. 76, III, c; Const. de 1891, art. 59, 5 1.॰, b, que panson a ser art. $60, \S 1 . \bullet, b$, na reforme do 1926 . 
concluir "que o Supremo deva sempre prover o recurso para julga: inválidas" as leis estaduais ${ }^{25}$.

Êsse caso de recurso é autorizado com base exclusivamente na presunção de constitucionalidade das leis federais. A aplicação da lei estadual pelo tribunal local contra uma lei federal contém, implícita ou explicitamente, uma declaração de inconstitucionalidade da norma federal. Num conflito entre a lei federal e a esta. dual, a primeira só pode ser preterida por motivo de inconstitucionalidade. Mas, como em favor da lei federal milita a presunção de constitucionalidade ${ }^{26}$, remete-se a questão ao Supremo Tribunal Federal, que é o órgão judiciário mais autorizado para interpretar a Constituição.

Por conseguinte, o recurso extraordinário com fundamento na letra c (aplicação de lei estadual contestada em face da Constituição ou de lei federal) resolve-se, finalmente, no caso da letra í do art. 101. III : "quando se questionar sôbre a vigência ou validade de lei federal em face da Constituição, e a decisão do tribunal local negar aplicação à lei impugnada."

25 A esta opinião acertada de A. Gonçalves DE Olverra (trab. cit., p. 46) julgamos oportuno aduzir os argumentos que se lêm no texto.

26 Diz Castro Nunzs: "Não sòmente o Judiciário mas qualcuer dos cutros cois poderes é intérprete do texto" (constitucional) "com igual autoridade coustitucional para ditar as regras da sua aplicação de acôrco com o entendimento que lhe derem... Dai resulta que as leis do Congresso e os atos de igual fôrça, ainda que emanados do Exect:tivo, são, quando argǘdos de inconstitucionais, presumidamente válidos. Presume-se que a legislatura agiu dentro des seus poderes constitucionais; de modo que na dúvido a Côrte se abstém de pronunciar a invalidade do ato. A oposição entre a Constituição e a lei deve ser tal que o juiz experimente uma clara e forte convicção - “a clear anju strong conviction" - da incompatibilidade entre ambes existente (Teoria e Prática do Judiciário, cit. @. 589-90).

A presunção de constitucionalidade cas leis tinha, entre aćs, amparo em texto l:gal expresso, o art. $13, \S 10$, da Lei $n .0^{\circ} 221$, de 1894, que faculta ao judiciério deixar da eplicar aos casos ocorrentes "as leis manifestamente inconstitutionais". Essa presunçäo estava ainda implicitadamente contida no art. 34 , ns. 33 e 34 , que declarave da compttência privativa da Uniäo "decretar as leis e resoluçöes necessáries an exercício dos poderes que pertencem à Uniăo" e "decretar as leis orgánicas para execuçăo completa da Conntituição".

Recordem-se tambem as seguintes palavras de CarLos MaxumiLIaNo: "Os tribunass só declaram a inconstikucionalidade de lé quando esta 6 evidente, näo deixa margem seria objeção em contrário. Portanto, se, entre duas interpretaçōes mais ou menos defersáveis, entre duas correntes de idéias apoiadas por jurisconsultos de valor, o Congresseo adotou uma, o seu ato prevalere". (Hermeneutica e Aplicacäo do Direito p. 313 ).

A constitucionalidade presumida das lyis stambém doutrina corrente nos Estades Unidos, embora na prática muitas leis sejam declaredas inconstitucionais apesar da regra da "duivida razoável": "It is be assumed that the legislature will not intentionslly pioilate the Constitution, and in cases of reasonable doubt the benefit of doubt, as a rule, is given in lavor the constitutionality of legislation. Although the doctrine of reasonables doubt is not always strictly followed by the courts in practice, it is more likely to applied in cases where the law in question has been enacted by a coordinate legislativs body. It must be remembered, however, that, in most instances, the Court actes by majority vote, so that, if a bare majority of the Courk think that a law is without doutt unconstitutional, they may so declare it, regardless of the contrary views of minority. Under such circunstances, it might reasonably be supposed that the Court, taken as a group, entertains some doubf as to the constitutionality of the statutes, which, under tho rule, should be resolved in its lavor'l (MAxkrws, op. cit., p. 226). 
Nesta última hipótese, ainda é a presunção de constitucionalidade da lei federal que fundamenta o recurso. Se a decisão da justiça local aplica a lei federal questionada, o recurso não cabe, porque aquela presunção foi acolhida pelo julgado. Se a lei federal deixoú de ser aplicada, então cabe o recurso, porque o tribunal local contrariou a presunção de constitucionalidade da lei federal, devendo pronunciar-se a respeito o órgão mais qualificado, que é o Supremo Tribunal Federal.

A diferença entre os dois casos está em que, na hipótese da letra $b$, a lei federal deixou de ser aplicada por declaração expressa da sua inconstitucionalidade, ao passo que, na hipótese da letra c, na qual também se deixou de aplicar a lei federal para aplicar a estadual, a inconstitucionalidade da norma federal pode estar contida de modo apenas implícito no julgado recorrido. Mas num e noutro caso, o que ocorre é a não aplicação da lei federal por motivo de inconstitucionalidade, motivo que estará expresso numa hipótese, mas que na outra estará expresso ou implícito.

Em ambos, o que autoriza o recurso é, pois, a presunção de constitucionalidade da lei federal. Assim como no caso da letra $b$ (não aplicação de lei federal por contrariar a Constituição) o Supremo faz prevalecer, não a lei federal inaplicada, mas a Constituição, com a inteligência que lhe der, também no outro caso (aplicação de lei estadual contra lei federal) o que tem a fazer o Supremo não é impor a lei federal, mas impor a Constituição, seja contra a lei estadual, seja contra a lei federal, conforme o alcance do texto constitucional. Em ambos os casos, o dever do Supremo é fazer prevalecer a Constituição; se há conflito entre lei federal e estadual, o prevalecimento da Constituição poderá importar, ou na aplicação da lei federal, ou na aplicação da lei estadual. Nesta última hipótese, o julgado recorrido deve subsistir.

Essa interpretação, que é a única verdadeira, está reforçada pelas disposições constitucionais referentes à intervenção federal nos Estados. Assim é que a Constituição de 1937, alterando nesta parte as anteriores" , só permite a intervenção para garantir a exocưção das leis federais mediante requisição do Supremo Tribunal Federal (art. 9.', parágrafo único). Por que se exige um pronunciamento do Supremo para obrigar os Estados, por via da intervenção, a cumprir as leis federais? Precisamente porque o Supremo Tri-

27 Op cit., ps. 127 e 128. E Qunrsara : “A interpretaçäo que a Suprema Côrte dos Estados Unidos - guardiā da Constituiçâo federal - tem dado aos podert nacionais e aos estaduais, principalmente a maneira como o mais alto tribunal norto americano tem interpretado a doutrina dos chamados poderes implícitos, tem sido o fator que mais há estimulado o fortalecimento do govêrno central" (QUintana, em La Loy de $31-7-42$ ). 
bunal, que é o órgão mais qualificado para interpretar a Constituiçäo, apreciará, em primeiro lugar, se as leis federais, tidas comc desrespeitadas pelo Estado, são ou não leis federais válidas. Se não forem válidas, ısto é, se otendem elas próprias a Constıtuiçäo, nào deve a intervenção ser requisitada, pois isto equivalerı a um constrangımento inconstitucional para os Estados, cuja esfera de ação propria quer o regime tederativo adotado na Constıtuçao que seja escrupulosamente respeitade. O prévio exame, pelo Supremo Irivunal, da valıdade das leis tederais para fins de intervençao nos Lstados corrobora a interpretação segundo a qual o Supiemo, ao connecer de um conflito entre lei. federal e lei estadual em recurso extraordunario, não tem por missão impor a lei tederal, mas impor a Constituição, embora, se fôr o caso, contra a lei federal.

Estes esclarecimentos se tornam perteitamente banas, quandos se toma como exemplo a repartição constitucional dos impostos, e é mais taxativa do que a repartição dos demais poderes. Ninglem ousaria afirmar que uma lei tederal instituindo um imposio privativo dos Estados devesse prevalecer sôbre a respectiva leı estadual. A situação há de ser a mesma com qualquer outra le1, desde que se trate, no caso, de competencia p̀rivatuva dos Estados.

14. Expasta a questão em tese, como o fizemos acima, nenkuma dificuldade maior pode surgir. Mas não é fácil, em alguns casos concretos ocorrentes, decidir se a matéria é da competencia privativa dos Estados, ou se é da competencia concorrente dos Es. tados e da União. Essa dificuldade é agravada com a aplicação do pruncípio constitucional dos poderes federaus implícitos. São principalmente os poderes implícitos, como anteriormente já observamos, que têm autorizado, com o beneplácito da Suprema Côrte, a ampliação da competencia federal nos Estados Unidos: "The imiplied powers of Congress are more numerous and extensive than? its express powers", diz Mathews, que, depois de enumerar vários exemplos, acrescenta: "Another illustration of implied power is found in the national police power, exercised by Congress for the protection of the public safety, morals and health" 28

$\mathrm{Na}$ Constituição de 1937 , não se pode dizer que os poderes implícitos da União sejam mais numerosos que os expressos, dada

28 "Il est d'autres matières où les organes fédéraux sont sompétents pour poser des prïncipes, cuonner des directives, firer les règles essentielles, et les or hanes d"Etati mombres" pour édicter les règles camplémentaires et procéder aux mesures d'application...; il dépend des premiers de donner des directives si nett.ss, si complètes et détail. lées, si impératives, que les seconds n'auront plus, quant aux mesures de complément cax d'application, de choir entre divers partis... Enfin, dans divers domaines, les or ananes fédéraux possédent une compétence dont rexercice est pour eux faculiatif. Tant gis'il $n^{\prime} u s e n t$ pas de cette taculté, les organes propres des "Etats-membres" ont eur-mêrzes pleine compétence dans cos domaines. Mais dü jour où les orqanes fédéraur accomplis. 
a grande amplitude dêstes últimos; ainda assim, os poderes federais implícitos são extensos, devido aos têrmos muito genéricos de alguns dos poderes expressos. E', aliás, fenômeno universal o alargamento da competência da União nos Estados Federais. A outorga, à Uniāo, do poder de estabelecer princípios, traçar diretrizes, formular quadros em certos assuntos, permite, na prática, que a União se substitua aos Estados em tais assuntos, bastando que imponha princípios minuciosos, diretrizes especificadas e quadros rígidos. A maior ou menor extensão dessas linhas gerais fica ao inteiro arbítrio da União". Em nossa atual Constituição, como na de 1934, êsse campo de competência mista ou concorrente é de grande amplitude, e ainda mais se alarga com o concurso dos poderes implícitos.

15. Figuremos alguns exemplos concretos. Entre nós, cabe aos Estados o poder de legislar sôbre sua organização judiciária, respeitados os princípios constitucionais (arts. 103 e 16, XXII). Mas a União, no uso de sua competência privativa para legislar sôbre processo (art. 16, XVI), prescreveu no art. 1.049 do Código de Processo Civil: "As leis de organização judiciária e os, regimentos internos dos Tribunais adaptar-se-ão às disposições dêste Código, que sôbre umas e outros prevalecerá." Eis aí uma aplicação dos poderes implícitos. A União, adotando uma nova sistemática processual, estipulou diversas normas substancialmente de organização judiciária (remoção e substituição de juizes, férias, etc.), que julgou essenciais ao bom êxito das novas normas processuais.

Por outro lado, o poder de legislar sôbre telefones pertence aos Estados, porque não se inclui nos poderes da União. Mas, como a União pode regular "a fiscalização e revisão das tarifas dos serviços públicos explorados por concessão" (art. 147), muitas disposições que adotar sôbre os serviços concedidos de telefones terão 'de ser aceitas como legítimas.

Ainda um caso. A isenção de tributos estaduais e municipais privativos (impostos ou taxas) cabe indiscutivelmente aos Estados e Municípios, porque quem tributa é que isenta. Se a Uniăo tivesse

\footnotetext{
ent des actes juridiques en ces matières, leurs décisions priment celles qu'ont pu prondro entérieurement les or ganes des "Etats-membres" et les abrogent, au moino dans la mesure où ellos les contredisent... Or, ces domaines mirtes, peu étendus den la première constitution fédéralo, lo sont au contraire beaucoup, et de plus en plus, dans los constitutions: fédóraleq ultérieures". (Ch. DuRand, Les Etats Fédéraux, Parie, 1930, pe. 126, 127 - 128).

29 Vejam-se, no primeiro fascículo desta Revista: Castro Nurzs, Problemas da

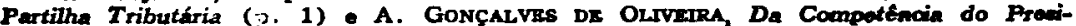
dente da Repúblice para Decretar a Bitributaçöo (p. 49).
} 
a faculdade de isentar livremente os contribuintes de tributos estaduais ou municipais, poderia levar Estados e Municípios à insolvabilidade. Mas a União, entre nós, já tem concedido tais isençĩes, ao regular matérias de sua competência privativa. O Código de Processo Civil isenta de selos os autos suplementares (art. 14, $\S 1^{\circ}$ ) e regula os casos de gratuidade da justiça (arts. $68 \mathrm{ss}$.) 0 Decreto-lei na ${ }^{\circ}$.200, de 1941 (organização e proteção da famíla) mandou que os Estados e Municípios concedessem isenções fisca ss para o casamento de pessoas pobres. aquisição de prédios peles recém-casados, reconhecimento de filhos naturais e constituição de bem de familia (art. 41). Outros exemplos existem, mas é desnecessário enumerá-los. A isenção é, em tais casos, outorgada com fundamento nos poderes implícitos que tern a União de regrular a matéria principal. Em que limite serão essas isençôes văli das, o Judiciário é quem o dirá no julgamento dos casos ocorrentes, e tendo em vista a necessidade de resguardar a sanidade das finanças estaduais e municipais.

16. Na Constituição, a competência privativa da União está em principio, enumerada no art. 16, mas em diversas das matéties ai previstas os Estados têm competência concorrente ou suplementar, seja originária, por fôrça da própria Constituição, seja por via de expressa delegação federal (arts. 17 e 18 ).

Nos casos previstos nestes dois últimos artigos, "desde que: o Poder Legislativo Federal ou o Presidente da República haja expedido lei ou regulamento sôbre a matéria, a lei estadual ter-se-á por derrogada nas partes em que fôr incompatível com a lei cu regulamento federal" (art. 18, parágrafo único).

Por outro lado, em outras disposiçōes constitucionais se enc.jntram ainda matérias da competência concorrente ou privativa da União, como, por exemplo: criar Territórios federais (art. 6. ${ }^{\circ}$ ) legislar sôbre providências que os Estados devam tomar, na esfera de sua competência, para execução de tratados comerciais, quando êles não cs tenham feito em tempo útil (art 10); regular a fiscalização das tarifas de serviços públìcos concedidos (art. 147), ets.

No domínio tributário, a competência exclusiva da União está regulada no art. 20; a dos Estados, no art. 23; a dos Municipios, no art. 28; e a competência concorrente da União e dos Estados. no artigo 24. Ainda no domínio tributário, há proibições para a União, os Estados e os Municípios no art. 32, e, e parágrafo único; para os Estados e Municípios, nos arts. 25 e 35, b; e para a Uniăo, nos arts. 20, II, e 34 .

A discriminação de competências mais rígidas é a dos poiteres tributárias, onde os possiveis conflitos entre leis da Uinião, dcs 
Estados e dos Município é mais fácil de resolver-se, quando se trate de tributos privativos. No caso da competência tributária concorrente para criar "outros impostos" além dos privativos, muitas dúvidas podem ocorrer, mas relativas, umas, à caracterização da existência, ou não, da bitributação, vedada pelo texto constitucional; outras, à competência constitucional para declarar essa tributação, e outras, finalmente, aos efeitos de semelhante declaração.

Nas demais matérias, saber se em certo caso se aplica a lei estadual ou a federal é, às vêzes, problema áspero, porque na aplicação dos poderes implícitos fica o Judiciário com grande arbítrio, como tem sucedido nos Estados Unidos. Note-se, porém, que a Constituição de 1937 deixou poucos assuntos à competência exclusiva dos Estados.

17. O que se disse acima sôbre a independência das leis estaduais, na esfera de ação exclusiva dos Estados, também se aplica às leis municipais. Quanto a estas, porém, o exame da exclusividade da competência não pode ser feito apenas tendo em vista a Constituição federal, porquanto, a não ser em matéria de impostos, a Constituiçăo (arts. 26 a 28) deirou ainda larga dose de discrição ao poder constituinte estadual para regular a administração municipal.

Num conflito entre lei federal, lei estadual e lei municipal, a primeira questão é saber se a matéria era, ou não, da competência federal, o que se resolve no estudo da Constituição federal. A megunda questão é saber se a matéria era da competência estadual ou da municipal, o que se verifica pelo exame, não só da Constituição federal, como ainda das Constituições estaduais. Se neste negundo exame se conclui que a matéria era privativa do Município, então a lei municipal tem primazia, deixando de aplicar-se a federal e a estadual.

Isso pode ocorrer, por exemplo, no tocante a um impôsto estadual privativo, que o Estado, por sua Constituição, tenha transferido aos Municípios, como permite o art. 28 da Constituição. A lei que se aplicará, na hipótese, é a municipal.

\section{a ATUAL SITUAÇão transtróRIa dos estados}

18. Resta saber se os princípios aqui expostos são válidos, ou não, no atual regime de administração dos Estados e Municipios regulados pelo Decreto-lei n. 1.202 , de 8-4-1939, alterado 
em muitas de suas disposiçōes pel̆o Decreto-lei $\mathrm{n}^{0} 5.511$, A 21-5-1943.

A Constituição determinou, no art. 176, que fôsse decretad $a$ intervenção nos Estados cujos Governadores não tivessem o mat dato confirmado. Assim se fêz em todos, com exceção do de Mina Gerais, para o qual se confirmou o mandato do Governador. Fc outro lado, o art. 181 dispunha:

“As Constituiçōes estaduais serão outorgadas pelk respectivos Governos, que exercerão, enquanto näo se rH! nirem as Assembléias Legislativas, as funçōes destas xas matérias da competência dos Estados".

Os governos estaduais a que se refere a Constituição seriar em Minas, o Governador e, nos demais Estados, os respectivos is terventores.

Entretanto, o Decreto-lei n. 1.202 criou em cada Estado, se excetuar o de Minas "an, um órgâo denominado Conselho Admiri trativo (primitivamente Departamento Administrativo), de nome ção do Presidente da República (art. 13). Discriminou a comp tência dêsse órgão (art. 17), a do Governador, ou Interveatc (arts. $60^{\circ}$ e $70^{\circ}$ ) e a dos Prefeitos (art 12). A função legislativ municipal ficou cabendo ao Prefeito (legislação provisória de eme gência) (art. 12, nova redação), e ao Prefeito em colaboração c $s$ o Conselho Administrativo (art. 17, a). A função legislativa est dual passou a competir ao Interventor, ou Governador (legislaç: provisória de emergência) (art. $6 .^{\circ}, \mathrm{V}$ ); ao Interventor ou Gove nador, em colaboração com o Conselho Administrativo (art. 17, a ficando ainda as leis estaduais sôbre numerosas matérias subordin das à prévia aprovação do Presidente da República (art. 32). I ainda estabelecido um sistema de recursos de autoridades mus cipais para as estaduais e de autoridades estaduais para as feder (art. 19).

Em todos os casos em que os decretos-leis estaduais depe dem de aprovação prévia do Presidente da República (art. 32), contrôle que a União exerce, por mão do Chefe de Estado, sôbı a legislação estadual não é apenas de legalidade ou constitucion lidade, mas também contrôle de oportunidade e conveniência. Estâ

30 Esta lei, equìparando os poderes do Governador de Minas ans dos Interyenton nos demais Estadios, equivale, embora sem a nomeação do "interventor" a que se ref, - art. 9.0 da Constituiçāo, à decretação da intervençāo naquele Estado. 
pois, os Estados, nessas matérias, estreitamente subordinados à Uniäo.

Dada, porém, a aprovação presidencial, o decreto-lei se completa como lei estadual, e só deve ser revogado por outra lei estadual, para a qual não basta um ato do Presidente da República, mas igualmente se exige o concurso dos órgãos estaduais (o Conselho Administrativo e o Interventor, ou Governador).

A questão a resolver é, entretanto, a seguinte : estando os Estados em tão estreita dependência da Uniăo, pode uma lei estadual ser aplicada, quando colidir com outra federal? Existe ainda, nesse regime, a esfera dos negocios peculiares dos Estados, em cujo âmbito a lei estadual expedida no uso de competência privativa gira em esfera independente da órbita das leis federais ?

O problema não é fácil. A lei federal colidente não vale como lei estadual, para o fim de revogar leis estaduais, porque, nos trâmites que presidem à elaboração dos decretos-leis estaduais' segundo as normas do Decreto-lei n.0 1.202, há formalidades que não são atendidas na elaboração das leis federais, como sejam a sanção do Interventor, ou Governador, e a audiência ou aprovação do Conselho Administrativo (arts. 6.9, IV, e 17, a).

A questão não se resolve, pois, em problema de vigência, pois, na hipótese, a lei estadual deve revogar-se por outra estadual, e a lei federal não vale como lei estadual. A questão é de supremacia, ou não, da lei federal.

Se os trâmites apontados para perfeição da lei estadual são exigidos por uma lei federal ordinária, outra lei federal ordinária pode diminuí-los, alterá-los ou substituí-los. Mas uma nova lei federal poderá dispor, por exemplo, que, no regime transitório em que se encontram os Estados, qualquer lei federal se aplicará nos Estados, apesar de colidir com qualquer outra lei estadual porventura existente? Não existe ainda alguma lei neste sentido. Daí nova pergunta : pode semelhante mandamento considerar-se implicito como decorrência do princípio de que as leis federais se aplicam em todo o território da República, salvo quando expressamente disponham em contrário?

Estando todos os Estados em regime de intervenção - poderá dizer-se - a validade das leis estaduais depende da autoridade que thes confere a lei federal ordinária que regula a intervenção. Portanto, se uma lei federal posterior entra em conflito com uma lei estadual, cuja validade foi outorgada por uma lei federal anterior, pode parecer que a validade que a primeira lei federal conferiu à lei estadual the foi retirada pela segunda lei federal. 
Os argumentos aqui figurados mostram a delicadeza da que tão, a qual, parece, deve ser justa em outros têrmos. O raciocíni acima imaginado conduz à destruição do sistema federativo.

A intervenção federal nos Estados não é, porém, um expr diente de tão largo alcance. Se assim fôsse, decretar a intervençã em um Estado ou reduzi-lo a território seriam a mesma coisa Ainda durante a intervenção o sistema federativo subsiste, porç - Estado continua com sua individualidade própria. A validéc da lei estadual, durante a intervenção, näo resulta da lei federı resulta da própria Constituição. O que provém da lei federal é autoridade do órgão capaz de expedir a lei estadual na vigência d intervenção.

A Uniāo, que pode regular os poderes do interventor (art. 9 da Constituição), pode alterar êsses poderes, limitá-los ou an pliá-los, e, portanto, determinar as condições em que o intervent te decretará leis estaduais válidas. Mas, uma vez decretadas essis leis, segundo a forma que thes foi prescrita, elas adquirem inde pendência, como ato do govêrno estadual, com a validade que Constituição atribui aos atos dos governos estaduais.

A União, podendo regular os poderes do interventor, pod estabelecer as condições em que as leis feitas pelo interventor adqu rem validade como leis estaduais. O que a lei federal regul: portanto, são as condiçōes de validade da lei estadual promulgác durante a intervenção, mas a validade mesma dessa lei resulta $\dot{c}$ Constituição, desde que observadas as condições exigidas .

Aos doutos compete esclarecer deśnitivamente a questão aq̣ focalizada de modo tão tosco. Mas, se se deve entender que Constituição está em vigor, isto é, que dentro dos seus quadro há uma esfera de competência federal e outra estadual, parec acertado dizer que essa duplicidade de competências subsiste n atual situação transitória dos Estados, malgrado o contrôle de opo tunidade e de conveniência que o Presidente da República exerc sôbre os atos dos governos estaduais. E, se assim é, num conflit de leis, não deve a lei federal prevalecer sôbre a estadual, se ; matéria regulada é da competência privativa dos Estados. 